\title{
International Instrument on Permitted Uses in Copyright Law
}

\author{
Reto M. Hilty • Kaya Köklü • Valentina Moscon • \\ Carlos Correa - Séverine Dusollier • \\ Christophe Geiger • Jonathan Griffiths • \\ Henning Grosse Ruse-Khan - Annette Kur • \\ Xiuqin Lin • Ryszard Markiewics • Sylvie Nérisson • \\ Alexander Peukert • Martin Senftleben • \\ Raquel Xalabarder
}

Published online: 4 February 2021

(C) The Author(s) 2021

\section{Preamble}

The Contracting Parties,

recalling

(1) that everyone has the right to take part in cultural life and to enjoy the benefits of scientific progress and its applications, and that creators have the right to benefit from the protection of the moral and material interests resulting from their scientific, literary or artistic productions;

For an introduction to the International Instrument, see the editorial by Reto M. Hilty and Valentina Moscon "International Instrument on Permitted Uses in Copyright Law - an Introduction" in this issue of IIC at https://doi.org/10.1007/s40319-020-01000-2. An annex with explanatory notes is available at https://www.ip.mpg.de/fileadmin/ipmpg/content/forschung/International_Instrument_Explanatory_ Note_2020-12-18.pdf.

R. M. Hilty

Project Lead (Chair); Director, Max Planck Institute for Innovation and Competition, Munich; Professor, Universities of Zurich and Munich (LMU), Munich, Germany

K. Köklü

Project Lead (Drafting); Former Research Fellow at the Max Planck Institute for Innovation and Competition, Munich; Qualified Lawyer, Düsseldorf, Germany

\section{Moscon $(\bowtie)$}

Project Lead (Drafting); Senior Research Fellow, Max Planck Institute for Innovation and Competition, Munich, Germany

e-mail: valentina.moscon@ip.mpg.de

\section{Correa}

Executive Director, South Centre, Geneva; Former Director of the Centre for Interdisciplinary Studies on Industrial Property and Economics Law; Professor, University of Buenos Aires (UBA) Faculty of Social Sciences, Buenos Aires, Argentina 
(2) that the encouragement of learning and the pursuit of scientific research, innovation and creativity are indispensable to sustainable human and economic development;

(3) that the promotion of education, science and the arts is a principal objective of the copyright system;

\title{
recognizing
}

4. the importance of copyright protection as an incentive and reward for literary and artistic creation of works, and the need to maintain a balance between the effective protection of right holders and the larger public interest, including, in particular, education, research and access to information;

\author{
S. Dusollier \\ Professor, Sciences Po, Paris, France \\ C. Geiger \\ Professor, University of Strasbourg, France; Affiliated Research Fellow at the Max Planck Institute \\ for Innovation and Competition, Munich, Germany
}

\section{J. Griffiths}

Professor, School of Law, Queen Mary University of London, London, UK

H. Grosse Ruse-Khan

Reader in International and European Intellectual Property Law, University of Cambridge Fellow, King's College Cambridge, UK; Co-Director of the Centre for Intellectual Property and Information Law (CIPIL), University of Cambridge, UK; Affiliated Research Fellow at the Max Planck Institute for Innovation and Competition, Munich, Germany

\section{A. Kur}

Professor, University of Stockholm and University of Munich (LMU); Affiliated Research Fellow at the Max Planck Institute for Innovation and Competition, Munich, Germany

X. Lin

Deputy Dean, Professor, School of Law, Xiamen University, Xiamen, Fujian, People's Republic of China

R. Markiewics

Professor, Jagiellonian University, Cracow, Poland

\section{S. Nérisson}

Maître de Conférences - UT Bordeaux Montaigne/IRDAP University Bordeaux, Bordeaux, France; Affiliated Research Fellow at the Max Planck Institute for Innovation and Competition, Munich, Germany

\section{A. Peukert}

Professor, Goethe University, Frankfurt, Germany

M. Senftleben

Director, Institute for Information Law (IViR), University of Amsterdam, Professor, University of Amsterdam, Amsterdam, The Netherlands

R. Xalabarder

Professor, Universitat Oberta de Catalunya (UOC), Barcelona, Spain 
5. that Contracting Parties have obligations to each other under treaties concerning copyright, and that nothing in this Instrument shall derogate from any such obligations, nor shall it prejudice any rights that a Contracting Party has under any such treaties, except where the exercise of those rights would cause a serious conflict or threat to the objectives of this Instrument;

6. that in accordance with Articles 7 and 8 of the TRIPS Agreement and the customary rules of public international law, copyright protection must be implemented in a manner conducive to social and economic welfare, and to a balance of rights and obligations;

7. the importance of the Development Agenda recommendations, adopted in 2007 by the General Assembly of the World Intellectual Property Organization, which aim to ensure that development considerations, including a normative framework that is tailored to the development needs of all WIPO Member States, form an integral part of the Organization's work;

8. that in using the flexibilities allowed by international treaties on the protection of copyright and related rights, including the flexibilities resulting from a balanced interpretation of the three-step test, Contracting Parties may adopt obligations aimed at achieving the primary objectives of copyright regarding the promotion of education, science and the arts;

9. that differences in the availability and scope of copyright-permitted uses in an increasingly interconnected world tend to undermine the attainment of the primary objectives of copyright protection;

10. that, in an era of rapid technological change, copyright law must develop in a manner that promotes freedom of competition;

therefore desiring to

11. further the abovementioned functions and objectives of copyright law;

12. exercise and maintain the regulatory flexibility of Contracting Parties in the area of copyright law;

13. foster freedom of expression and information and further social, political and cultural objectives by setting out uses of copyrighted works that Contracting Parties shall permit;

14. control anticompetitive practices by right holders.

\section{A. Permitted Uses}

\section{Freedom of expression and information}

1. Contracting Parties shall permit uses serving freedom of expression and information to the extent justified by the purpose of the use.

2. Such uses shall include those for purposes such as:

a) quotation of works which have been lawfully made available to the public;

b) reporting of news and other matters of public interest;

c) criticism, review, parody and caricature;

d) search, organization and analysis of data for information purposes; 
e) any utilization of legislative, administrative and judicial works, including international treaties, as well as official translation of such works.

\section{Social, political and cultural objectives}

1. Contracting Parties shall permit uses serving social, political and cultural objectives to the extent justified by their purpose.

2. Such uses shall include those for purposes such as:
a) private utilization;
b) benefiting persons with disabilities;
c) education;
d) research;
e) preservation or restoration of works, by libraries, museums and archives;
f) reproducing and making available to the public of orphan works by libraries, museums and archives;
g) ensuring public security and the proper performance of administrative, parliamentary or judicial proceedings.

\section{Use of software}

Contracting Parties shall permit the use of software for purposes such as:

a) enabling the proper functioning of a computer program in accordance with legitimate uses for which it was acquired;

b) testing and reverse engineering;

c) enabling interconnection and interoperability of products offered, or used for provision of services, on derivative markets.

\section{Uses with minimal significance}

1. Contracting Parties shall permit uses with minimal significance.

2. Such uses shall include but are not limited to
a) incidental uses of a work in another work or material;
b) temporary uses which are necessary to enable a lawful use;
c) any other uses which have minimal or no independent economic significance.

\section{Free circulation}

1. Contracting Parties shall ensure that further circulation of goods is not unduly impeded by copyright.

2. In particular, if copies of a protected work are made available in tangible form or on data carriers by the right holder or with the right holder's consent, it shall be permitted to

a) re-sell such copies within the territory where they were subject to an authorized sale;

b) offer such copies for public lending by public service institutions. 


\section{B. General Principles of Implementation}

\section{Effectiveness}

1. Contracting Parties shall adopt the measures necessary to ensure the effective application of this Instrument.

2. Nothing shall prevent Contracting Parties from determining the appropriate method of implementing the provisions of this Instrument within their own legal system and practice.

\section{Three-step test}

1. Contracting Parties agree that it shall be a matter for legislation of Contracting Parties to permit uses in certain special cases, provided that they do not conflict with a normal exploitation of the work and do not unreasonably prejudice the legitimate interests of the right holder ("three-step test").

2. The conditions in B.II.1. shall be considered as a whole in a comprehensive overall assessment and must be interpreted in a manner that respects the legitimate interests of third parties, including interests deriving from human rights and fundamental freedoms, interests in competition and other public interests, notably in scientific progress and cultural, social or economic development.

3. In assessing whether the extent of permitted use complies with the conditions in B.II.1., Contracting Parties shall in particular take into account

a) any remuneration or compensation provided to the right holder;

b) the type of right holder;

c) the type of work;

d) the remaining term of protection;

e) the commercial or non-commercial nature of the use;

f) the market situation; and

g) the extent to which the creator and the source are mentioned.

4. The scope of permitted uses shall be interpreted according to their purposes.

\section{Technological protection measures}

Contracting Parties shall take appropriate measures to ensure that legal protection and effective legal remedies against the circumvention of effective technological measures do not prevent beneficiary persons from enjoying the permitted uses provided for in this Instrument.

\section{No contracting out}

Contracting Parties shall ensure that contractual terms in agreements between right holders and users do not unreasonably impede the benefits of permitted uses according to this Instrument. 


\section{Participation of the creator}

Contracting Parties shall ensure that the creator of a work is entitled to a reasonable share of any remuneration or compensation paid for the permitted use of that work.

\section{Right of attribution}

To the extent that it is reasonable to do so, the source and the name of the creator shall be mentioned in all cases of permitted use.

\section{Related rights}

It is understood that the permitted uses provided for by this Instrument apply mutatis mutandis to related rights to the extent justified by the purpose of the use.

\section{Competition; Abuse}

\section{Application of competition law}

Contracting Parties shall ensure that the exercise of exclusive rights in works and related rights is subject to the general rules and principles regulating competition.

\section{Compulsory licensing in case of abuse}

1. Contracting Parties shall ensure compulsory licenses for the use of works and related rights in case of abusive conduct by right holders.

2. Such abuse may concern, but is not limited to

a) refusal to license a work or other subject-matter where access to and use of that work or other subject-matter is indispensable on a derivative market;

b) excessive pricing due to the monopolistic structure or other malfunctioning of the relevant market.

Funding Open Access funding enabled and organized by Projekt DEAL..

Open Access This article is licensed under a Creative Commons Attribution 4.0 International License, which permits use, sharing, adaptation, distribution and reproduction in any medium or format, as long as you give appropriate credit to the original author(s) and the source, provide a link to the Creative Commons licence, and indicate if changes were made. The images or other third party material in this article are included in the article's Creative Commons licence, unless indicated otherwise in a credit line to the material. If material is not included in the article's Creative Commons licence and your intended use is not permitted by statutory regulation or exceeds the permitted use, you will need to obtain permission directly from the copyright holder. To view a copy of this licence, visit http:// creativecommons.org/licenses/by/4.0/.

Publisher's Note Springer Nature remains neutral with regard to jurisdictional claims in published maps and institutional affiliations. 